\title{
PRAKTIK PELAYANAN PUBLIK DI DAERAH : OPTIMALISASI PENYELENGGARAAN PELAYANAN PUBLIK BERDASARKAN KINERJA ORGANISASI PERANGKAT DAERAH DI KABUPATEN NGANJUK
}

\author{
*Berlian Tyasotyaningarum ${ }^{1)}$, Ajie Hanif Muzaqi ${ }^{2)}$ \\ 1), 2) Fakultas Ilmu Sosial dan Ilmu Politik Universitas Kadiri, Indonesia \\ *Email Korespondensi: berlian.tyasotyaningarum@unik-kediri.ac.id
}

\begin{abstract}
Abstrak
Reformasi pelayanan publik di Kabupaten Nganjuk dilakukan dalam mewujudkan tata kelola pemerintah yang efektif dan efisien. Pelaksanaan pelayanan kepada masyarakat secara esensial menunjang implementasi pelaksanaan otonomi daerah yang dilandasi oleh budaya kerja yang tinggi. Oleh karena itu penting sekali untuk dianalisis terkait bagaimana optimalisasi penyelenggaraan pelayanan publik dalam mewujudkan tata kelola pemerintah yang efektif dan efisien berdasarkan kinerja OPD di Kabupaten Nganjuk. Analisis menggunakan indikator kinerja yang berorientasi pada hasil. Indikator kinerja berorientasi pada hasil dipilih karena kawasan prioritas berisi kinerjadan hasil kualitas pelayanan pubik. Aspek indikator kerja yang dipilih adalah efektivitas dan kepuasan. Pendekatan yang digunakan dalam penulisan ini adalah pendekatan kualitatif berdasarkan kajian kepustakaan. Metode pengumpulan data yang digunakan adalah data sekunder yang berupa teori-teori relevan diperoleh dengan metode telaah pustaka. Metode pengumpulan data yang digunakan adalah data sekunder yang berupa teori-teori relevan diperoleh dengan metode telaah pustaka. Berdasarkan hasil analisis menunjukkan bahwa kinerja pemerintah daerah Kabupaten Nganjuk dalam peningkatan pelayanan publik sudah dilakukan secara optimal. Dimana target dalam rencana kerja semua terpenuhi. Selain itu program peningkatan pelayanan publik sudah sesuai dengan visi, misi, tujuan dan sasaran di Kabupaten Nganjuk. Dengan demikian, program capaian kinerja pada peningkatan pelayanan masyarakat dapat dikatakan efektif
\end{abstract}

Kata Kunci: Pelayanan Publik; Kinerja; Kabupaten Nganjuk

\begin{abstract}
Public service reform in Nganjuk Regency is carried out in realizing effective and efficient government governance. The implementation of services to the community essentially supports the implementation of regional autonomy which is based on a high work culture. Therefore, it is very important to analyze in relation to how to optimize the implementation of public services in realizing effective and efficient government governance based on the performance of OPD in
\end{abstract}


Nganjuk Regency. The analysis uses performance indicators that are results-oriented. Resultsoriented performance indicators were chosen because the priority area contains the performance and results of the quality of public services. Aspects of the selected work indicators are effectiveness and satisfaction. The approach used in this paper is a qualitative approach based on literature review. The data collection method used is secondary data in the form of relevant theories obtained by the literature review method. The data collection method used is secondary data in the form of relevant theories obtained by the literature review method. Based on the results of the analysis, it shows that the performance of the local government of Nganjuk Regency in improving public services has been done optimally. Where the targets in the work plan are all met. In addition, the public service improvement program is in accordance with the vision, mission, goals and objectives in Nganjuk Regency. Thus, the performance achievement program in improving community services can be said to be effective

Keywords: Public service; Performance; Nganjuk Regency

\section{PENDAHULUAN}

Pelayanan publik merupakan segala bentuk jasa pelayanan, baik dalam bentuk barang publik maupun jasa publik yang prinsipnya menjadi tanggungjawab dan dilaksanakan oleh instansi pemerintah di pusat, di daerah, dan dilakukan BUMN atau BUMD dalam upaya pemenuhan kebutuhan masyarakat maupun dalam rangka pelaksanaan ketentuan peraturan perundang-undangan (Ratminto \& Winarsih, 2007). Munculnya gerakan New Public Management (NPM) di negara-negara maju telah menimbulkan tekanan terhadap praktik penyelenggaraan layanan publik di negara-negara tersebut. Keinginan untuk melakukan tranformasi praktik manajemen pelayanan publik dengan mengadopsi nilai-nilai yang selama ini berkembang di sektor bisnis, seperti entrepreneurship, kepedulian pada pengguna, serta orientasi pada revenue-generating dan penghasilan, telah mendorong terjadinya perubahan yang sangat berarti dalam praktik penyelengaraan layanan publik (Osborne, 1993)

Penyelenggaraan pelayanan publik yang dilaksanakan oleh instansi pemerintahan dalam berbagai sektor pelayanan, terutama yang menyangkut kebutuhan dasar masyarakat masih belum berjalan optimal kinerjanya. Kondisi penyelenggaraan pelayanan publik saat ini masih belum memadai, menurut Mohammad dalam (Hardiyansyah, 2018) pelayanan public masih memiliki bebagai kelemahan antara lain kurang responsif, kurang informatif, kurang accessible, kurang koordinasi, birokratis, kurang mau mendengar keluhan, atau 
aspirasi masyarakat serta inefisien. Berikut ini hasil survei yang dilakukan oleh Litbang Kompas terhadap 885 responden (tingkat kepercayaan 95\%) terkait kondisi pelayanan publik di Indonesia dalam (Hardiyansyah, 2018)

\section{Tabel 1 Kondisi Pelayanan Publik di Indonesia}

\begin{tabular}{|c|l|c|}
\hline No & Kondisi Pelayanan Publik & Persentase \\
\hline 1 & Ketidakpastian waktu & $62,9 \%$ \\
\hline 2 & $\begin{array}{l}\text { Ketidakpastian biaya/ aparat } \\
\text { gampang disuap }\end{array}$ & $58 \%$ \\
\hline 3 & Aparat tidak disiplin & $65,3 \%$ \\
\hline \multicolumn{2}{|c|}{ Sumber : (Hardiyansyah, 2018) } \\
\hline
\end{tabular}

Berdasarkan data tersebut menunjukkan bahwa fenomena kondisi pelayanan publik tersebut hampir terjadi di berbagai kantor pelayanan publik di Indonesia. Kecenderungan model klasik dalam pelaksanaan pelayanan publik tersebut menimbulkan patologi birokrasi pada pelayanan publik seperti kondisi pelayanan publik di atas. Padahal dalam penyelenggaraan pelayanan publik dihadapkan pada berbagai tantangan seperti perkembangan teknologi, perkembangan lingkungan serta perkembangan ilmu pengetahuan masyarakat.

Perkembangan masyarakat dan kebutuhan yang semakin beragam mendorong pemerintah untuk lebih fleksibel dalam merespon setiap kondisi yang kompleks dan berubah dengan cepat. Hal tersebut sulit dilakukan jika para penentu kebijakan hanya mampu menggunakan satu metode, yaitu pelayanan yang dihasilkan oleh birokrasinya sendiri. Bagi jenis pelayanan yang bersifat monopoli, adanya perubahan kebijakan pemerintah dapat berdampak dan menjadi masalah. Hal tersebut menuntut pemerintahan entrepreneurial mulai beralih ke sistem yang memisahkan antara keputusan kebijakan (mengarahkan) dan pemberian pelayanan (mengayuh).

Pemerintah sudah seharusnya menganut paradigma customer driven (berorientasi kepentingan masyarakat) dalam memerikan pelayanan kepada masyarakat luas, mempersiapkan seluruh perangkat untuk memenuhi paradigma tersebut secara sistemik 
(sejak masukan-proses-keluaran hasil/ dampak), sehingga terwujud pelayanan publik yang berkualitas (yang sedapat mungkin tangible, reliabel, responsive, aman, dan penuh empati dalam pelaksanaannya). Sehingga menurut Saefullah dalam (Hardiyansyah, 2018) untuk memberikan pelayanan publik yang lebih baik perlu ada upaya untuk memahami sikap dan perubahan kepentingan publik sendiri. Perubahan kehidupan dunia yang begitu cepat mempunyai pengaruh yang cepat pula terhadap perubahan sikap dan perilaku masyarakat secara umum. Kualitas layanan yang baik merupakan hal yang penting untuk mencapai kesuksesan (Oliver \& Rust, 1994), di mana kualitas layanan yang baik akan menyebabkan kepuasan pelanggan (Wood, 2008).

Salah satu dari delapan area perubahan reformasi birokrasi adalah pelayanan publik, dengan hasil yang diharapkan berupa pelayanan prima sesuai kebutuhan dan harapan masyarakat. Pelayanan publik merupakan salah satu agenda prioritas dalam reformasi yng diarahkan pada peningkatan mutu dan kualitas. Dengan demikian penting sekali untuk dilakukan reformasi pelayanan yang sesuai dengan perkembangan teknologi dan ilmu pengetahuan.

Pemerintah daerah sebagai penyedia pelayanan publik selalu dituntut untuk meningkatkan kualitas layanan agar semua masyarakat dapat menikmati layanan. Guna meningkatkan kualitas pelayanan publik perlu adanya strategi pelayanan prima. Orientasi dari pelayanan prima adalah kepuasan masyarakat pengguna layanan. Membangun pelayanan prima harus dimulai dan mewujudkan atau meningkatkan profesionalisme SDM untuk dapat memberikan pelayanan yang terbaik, mendekati atau melebihi standar pelayanan yang ada (Sedarmayanti, 2004). Beberapa daerah, termasuk kabupaten Nganjuk sudah memulai melakukan reformasi pelayanan publik.

Perencanaan pelayanan publik hendaknya selalu memperhatikan isu-isu dan permasalahan yang pastinya akan di hadapi masyarakat agar arah penyelenggaraan pelayanan publik menjadi tepat sasaran. Oleh karena itu penting adanya antisipasi melalui perencanaan yang matang dan komprehensif, sehingga arah penyelenggaraan pelayanan publik sesuai dengan tujuan pembangunan daerah.Dengan memperhatikan isu-isu dan permasalahan pelayanan publik yang terjadi, membuat kualitas penyelenggaraan 
pelayanan publik menuju ke arah good governance yang berdampak pada kualitas pelayanan publik.

Berkaitan dengan isu-isu dan masalah pembangunan yang akan dihadapi Kabupaten Nganjuk pada tahun 2018-2023 tidak bisa dilepaskan dengan permasalahan dan isu pembangunan provinsi dan nasional. Berdasarkan rencana strategis kabupaten Nganjuk pada tahun 2018 - 2023, secara umum isu dan permasalahan yang dihadapi antara lain : (1) Tuntutan masyarakat untuk memberikan pelayanan yang prima; (2) Adanya tuntutan akuntabilitas tata pengelolaan pemerintahan; (3) Perkembangan Iptek yang pesat tidak dibarengi dengan semangat SDM untuk meningkatkan kemampuannya;.(4) Ekspektasi terhadap produk hukum daerah yang sesuai dengan kebutuhan masyarakat; (5) Dinamika pengorganisasian dan ketatalaksanaan perangkat daerah ; (6). Membangun komitmen seluruh aparatur dalam melaksanakan tupoksi untuk mewujudkan komitmen; (7) Meningkatkan komitmen aparatur dalam menyelenggarakan Pemerintahan, pembangunan dan pelayanan masyarakat. Berdasarkan permasalah tersebut, Kabupaten Nganjuk merencanakan beberapa program kerja untuk melakukan reformasi pelayanan publik.

Reformasi pelayanan publik di Kabupaten Nganjuk dilakukan dalam mewujudkan tata kelola pemerintah yang efektif dan efisien. Pelaksanaan pelayanan kepada masyarakat secara esensial menunjang implementasi pelaksanaan otonomi daerah yang dilandasi oleh budaya kerja yang tinggi. Oleh karena itu penting sekali untuk dianalisis terkait bagaimana optimalisasi penyelenggaraan pelayanan publik dalam mewujudkan tata kelola pemerintah yang efektif dan efisien berdasarkan kinerja OPD di Kabupaten Nganjuk.

\section{TINJAUAN PUSTAKA}

\section{a. Pelayanan Publik}

Pelayanan publik adalah sebagai pemberi layanan atau melayani masyarakat, sesuai dengan aturan pokok atau tata cara yang berlaku. Pemerintah pada kodratnya adalah pelayanan kepada masyarakat, tidak mungkin melayani untuk dirinya sendiri, serta menciptakan suasana atau kondisi yang memungkinkan setiap anggota masyarakat dengan mengembangkan kemampuan demi tercapainya tujuan bersama (Kurniawan, 2016). 
Pelayanan publik adalah, segala bentuk dalam kegiatan pelayanan yang dilakukan oleh pihak penyelenggara pelayanan publik yang bertujuan sebagai upaya pemenuhan kebutuhan publik serta pelaksanaannya berdasarkan perundang-undangan yang berlaku (Mahmudi, 2005).

Penyelenggaraan pelayanan publik dapat dilaksanakan berdasarkan asas-asas umum yang sudah diterapkan berdasarkan good governance. Asas pelayanan publik bertujuan memberikan memberikan pelayanan yang memuaskan bagi pengguna jasa, pelayanan harus mempunyai asas sebagai berikut (Menpan, 2004): Transparansi, Akuntabilitas, Kondisional, Partisipatif, Kesamaan Hak, Keseimbangan Hak dan Kewajiban, Fungsi asas-asas umum pemerintahan yang baik di dalam penyelenggaraan pelayanan publik adalah sebagai acuan, pedoman, atau penuntun oleh pemerintah atau para pejabat instansi dalam rangkapenerapan good governance.

Pemerintah daerah sebagai penyedia pelayanan publik selalu dituntut untuk meningkatkan kualitas layanan agar semua masyarakat dapat menikmati layanan. Guna meningkatkan kualitas pelayanan publik perlu adanya strategi pelayanan prima. Pelayanan prima merupakan pelayanan berkualitas yang berusaha memberikan nilai optimal yang maksimal agar dapat memenuhi permintaan yang dibutuhkan oleh penggunanya. Karena inti dari kualitas pelayanan adalah kepuasan pelanggan. Masalah kualitas pelayanan menjadi salah satu kendala, dalam hal ini telah memasuki dunia persaingan dan melohat persaingan yang semakin ketat antar institusi (Puspitasari, 2019).

Prinsip dari pelayanan prima adalah mengutamakan kepentingan pelanggan. Tujuan dari pelayanan prima untuk memberikan layanan yang dapat memuaskan dan terpenuhinya kebutuhan masyarakat atau pelanggan. Dasar dari penyedia layanan yang berkualitas atau prima kepada masyarakat adalah "layanan adalah otoritas". Tentunya dalam bisnis atau sektor swasta, layanan selalu bertarget atau ditargetkan pada profil atau keuntungan perusahaan. Menurut (Sutopo, 2003) pelayanan prima yang ditujukan untuk masyarakat pada dasarnya bukan mencari keuntungan, tetapi untuk memberikan pelayanan dengan baik atau terbaik sesuai kebutuhan masyarakat. 


\section{b. Kinerja Birokrasi}

Kinerja merupakan terjemahan dari "performance" yang sering diartikan sebagai penampilan, unjuk rasa atau prestasi (Keban, 2004) Kinerja atau reformance merupakkan gambaran mengenai tingkat pencapaian pelaksanaan suatu kegiatan, program atau kebijakan dalam mewujudkan sasaran, tujuan, misi dan visi organisasi yang tertuang dalam strategic planning suatu organisasi (Mahsun, 2006). Menurut Bernardin dan Russel dalam (Sulistiyani \& Rosidah, 2003) kinerja merupakan catatan outcome yang dihasilkan dari fungsi pegawai tertentu atau kegiatan yang dilakukan selama periode tertentu. Berdasarkan beberapadefinisi tersebut, kinerja merupakan pencapaian hasil kerja terhadap pelaksanaan sutu kegiatan, program maupun fungsi pegawai tertentu yang dilakukan selama periode waktu tertentu.

Berkaitan dengan konsep kinerja, Rummler dan Brache dalam (Sudarmanto, 2009) mengemukakan tiga level kinerja, yaitu :

1. Kinerja Organisasi

Merupakan pencapaian hasil (outcome) pada level atau unit analisis organisasi. Kinerja pada level organisasi ini terkait dengan tujuan organisasi, rancangan organisasi, dan manajemen organisasi

2. Kinerja Proses

Merupakan kinerja pada proses tahapan dalam menghasilkan produk atau pelayanan. Kinerja pada level proses ini dipengaruhi oleh tujuan proses, rancangan proses, dan manajemen proses.

3. Kinerja Individu

Merupakan pencapaian atau efektivitas pada tingkat pegawai atau pekerjaan. Kinerja pada level ini dipengaruhi oleh tujuan pekerjaan, rancangan pekerjaan, dan manajemen pekerjaan serta karakteristik individu

Berdasarkan ketida level kinerja di atas, dalam tulisan ini yang dikaji terkait kinerja organisasi. Kaian difokuskan pada kemampuan Organisasi Perangkat Daerah (OPD) dalam melaksanakan kinerja sesuai dengan rencana kerja, sasaran, tujuan, misi dan visi organisasi. Dengan demikin kinerja OPD menjadi pokok dalam optimalisasi penyelenggaraan pelayanan publik di Kabupaten Nganjuk. 
(Ratminto \& Winarsih, 2007) mengemukakan bahwa untuk mengukur kinerja organisasi bisa menggunakan dua jenis indikator, yaitu indikator yang berorientasi pada proses atau indikator yang berorientasi pada hasil. Ukuran yang berorientasi pada proses adalah sebagai berikut:

1. Responsivitas, yaitu mengukur daya tanggap providers terhadap harapan, keinginan, dan aspirasi serta tuntutan customers

2. Responsibilitas adalah ukuran yang menunjukkan seberapa besar tingkat kesesuaian antara penyelenggara pemerintahan dengan hukum atau peraturan dan prosedur yang telah ditetapkan

3. Akuntabilitas merupakan suatu ukuran yang menunjukkan seberapa besar tingkat kesesuaian antara penyelenggara pemerintahan dengan ukuranukuran eksternal yang ada di masyarakat dan dimiliki stakeholders, seperti nilai dan norma yang berkembang dalam masyarakat

4. Keadaptasian adalah ukuran yang menunjukkan daya tanggap organisasi terhadap tuntutan perubahan yang terjadi dilingkungan

5. Kelangsungan hidup berarti seberapa jauh pemerintah atau program pelayanan dapat menunjukkan kemampuan untuk terus berkembang dan bertahan hidup dalam berkompetisi dengan daerah atau program lain.

6. Keterbukaan atau transparansi adalah prosedur/tatacara, penyelenggaraan pemerintahan dan hal-hal lain yang berkaitan dengan proses pelayanan umum wajib diinformasikan secara terbuka agar mudah diketahui dan dipahami oleh masyarakat, baik diminta maupun tidak.

7. Empati merupakan perlakuan atau perhatian pemerintah atau penyelenggara jasa pelayanan atau providers terhadap isu-isu aktual yang sedang berkembang di masyarakat.

Indikator yang berorientasi pada hasil menurut (Ratminto \& Winarsih, 2007) antara lain :

1. Efektivitas Tercapainya suatu tujuan yang telah ditetapkan baik itu dalam bentuk target, sasaran jangka panjang maupun misi organisasi publik. Akan tetapi pencapaian tujuan organisasi publik ini harus juga mengacu pada visi organisasi. 
2. Produktivitas merupakan ukuran yang menunjukkan kemampuan organisasi publik untuk menghasilkan keluaran yang dibutuhkan oleh masyarakat

3. Efisiensi perbandingan terbaik antara keluaran dan masukan. Idealnya organisasi publik harus mampu menyelenggarakan suatu jenis pelayanan tertentu dengan masukan (biaya dan waktu) yang sesedikit mungkin

4. Kepuasan seberapa jauh organisasi publik dapat memenuhi kebutuhan karyawan dan masyarakat

Dari pemaparan indikator kinerja di atas, tulisan ini menggunakan indikator kinerja yang berorientasi pada hasil. Indikator kinerja berorientasi pada hasil dipilih karena kawasan prioritas berisi kinerjadan hasil kualitas pelayanan pubik. Aspek indikator kerja yang dipilih adalah efektivitas dan kepuasan.

\section{METODE PENULISAN}

Pendekatan yang digunakan dalam penulisan ini adalah pendekatan kualitatif berdasarkan kajian kepustakaan. Pemilihan pendekatan ini diharapkan dapat memberikan gambaran secara detail mengenai optimalisasi penyelenggaraan pelayanan publik di Kabupaten Nganjuk. Dalam hal ini penulis membuat gambaran mengenai permasalahan dalam pelayanan publik dan program dalam mengatasi permasalahan tersebut, kemudian juga menggambarkan terkait capaian kinerja program.

Metode pengumpulan data yang digunakan adalah data sekunder yang berupa teori-teori relevan diperoleh dengan metode telaah pustaka. Selain itu data-data rencana kerja dari kabupaten Nganjuk serta dokumen laporan kinerja kabupaten Nganjuk. Prosedur penyusunan tulisan ini telah melalui langkah-langkah yang sistematis, sehingga memperoleh hasil kajian yang lengkap dan struktur. Langkah-langkah tersebut antara lain : menemukan dan merumuskan masalah, mencari dan menyeleksi sumber-sumber kepustakaan yang relevan, menganalisis data-data untuk menjawab permasalahan, serta menarik kesimpulan. 


\section{HASIL DAN PEMBAHASAN}

\section{a. Program Peningkatan Tata Kelola dan Reformasi pada Pelayanan Publik di} Kabupaten Nganjuk

Peningkatan Tata Kelola dan Reformasi Birokrasi pada pelayanan publikdi Kabupaten Nganjuk dilatar belakangi belum terlaksananya reformasi birokrasi sebelum tahun 2018. Akar permasalahan dari masalah ini adalah adanya mindset yang kurang sepahaman pada semua stakeholder dalam penerapan reformasi birokasi. Hal ini menyebabkan akuntabilitas kinerja Organisasi Perangkat Daerah (OPD) di kabupaten Nganjuk kurang menunjukkan kinerja yang baik. Dimana kurang adanya penyelarasan antara perencanaan program-program yang ada pada seluruh organisasi perangkat derah di Kabupaten Nganjuk. Berdasarkan permasalah tersebut, Kabupaten Nganjuk merencanakan beberapa program kerja untuk melakukan reformasi pelayanan publik.

Program optimalisasi pelayanan publik di Kabupaten Nganjuk tertuang dalam rencana strategis sekretariat daerah Kabupaten Nganjuk. Secara umum, untuk mendorong perwujudan visi dan misi periode 2018- 2023, Sekretariat Daerah Kabupaten Nganjuk mengupayakan sinergi empat pemangku kepentingan pembangunan, yaitu pemerintah daerah, masyarakat, dunia akademik, dan dunia usaha. Strategi dan arah kebijakan pembangunan daerah tahun 2018-2023 disusun berdasarkan visi dan misi yang telah ditetapkan dan dengan memperhatikan permasalahan pembangunan daerah serta isu-isu strategis yang terkait dengan pembangunan di Kabupaten Nganjuk. Seluruh program yang akan dilaksanakan oleh Sekretariat Daerah Kabupaten Nganjuk dalam kurun waktu 5 (lima) tahun (Tahun 2018-2023). Sehubungan dengan reformasi pelayanan publik di kabupaten Nganjuk, Pemerintah Daerah Kabupaten Nganjuk sudah mengagendakan reformasi birokrasi dalam penyelenggaraan pelayanan publik. Ada beberapa program dalam peningkatan pelayanan publik di kabupaten Nganjuk. Program tersebut digambarkan dalam table berikut ini.

Sehubungan dengan reformasi pelayanan publik di kabupaten Nganjuk, Pemerintah Daerah Kabupaten Nganjuk sudah mengagendakan reformasi birokrasi dalam penyelenggaraan pelayanan publik. Ada beberapa program dalam penyelenggaraan 
pelayanan publik di kabupaten Nganjuk. Program tersebut digambarkan dalam table berikut ini.

Tabel 2

Program Optimalisasi Pelayanan Publik di Kabupaten Nganjuk

\begin{tabular}{|l|l|}
\hline No & \multicolumn{1}{|c|}{ Program } \\
\hline 1 & Program Pelayanan Administrasi Perkantoran \\
\hline 2 & Program Peningkatan Sarana dan Prasarana Aparatur \\
\hline 3 & Program Peningkatan Disiplin Aparatur \\
\hline 4 & Program Peningkatan Kapasitas Sumber Daya Aparatur \\
\hline 5 & $\begin{array}{l}\text { Program Peningkatan Pengembangan Sistem Pelaporan Capaian } \\
\text { Kinerja dan Keuangan }\end{array}$ \\
\hline 6 & $\begin{array}{l}\text { Program Peningkatan Pelayanan Kedinasan Kehumasan dan } \\
\text { Keprotokolan }\end{array}$ \\
\hline 7 & Program Koordinasi Peningkatan Kualitas Pelayanan Masyarakat \\
\hline 8 & Program Peningkatan Kapasitas Kelembagaan \\
\hline
\end{tabular}

Sumber: (Sekertariat Daerah Kabupaten Nganjuk, 2019)

Salah satu program dalam optimalisasi pelayanan publik dalam rencana kerja Sekretariat Daerah Kabupaten Nganjuk Tahun 2020 adalah program koordinasi peningkatan kualitas pelayanan masyarakat. Pada program tersebut terdapat beberapa kegiatan untuk meningkatkan kualitas pelayanan publik di Kabupaten Nganjuk.

Tabel 3

Program Koordinasi Peningkatan Pelayanan Masyarakat

\begin{tabular}{|c|l|}
\hline No & \multicolumn{1}{|c|}{ Kegiatan } \\
\hline 1 & $\begin{array}{l}\text { Fasilitasi kegiatan survey kegiatan masyarakat pada masing-masing } \\
\text { perangkat daerah }\end{array}$ \\
\hline 2 & Evaluasi dan review SOP \\
\hline 3 & Pelaksanaan penilaian unit pelayanan publik \\
\hline 4 & Pembinaan/ sosialisasi di bidang ketatalaksanaan \\
\hline 5 & Implementasi dan evaluasi pelaksanaan reformasi birokrasi \\
\hline 6 & Inovasi pelayanan publik \\
\hline
\end{tabular}

Sumber: (Sekertariat Daerah Kabupaten Nganjuk, 2019)

Indikator pencapaian kinerja pada program koordinasi penigkatan kualitas pelayanan masyarakat berupa presebtase OPD yang nilai survey kepuasan masyarakat lebih besar sama dengan "baik". Pada program tersebut terdapat enam kegiatan untuk menunjang peningkatan pelayanan publik. Setiap kkegiatan juga mempunyai indikator 
untuk menilai pencapaian kinerjanya. Berikut ini merupakan indikator pada setiap kegiatan :

Tabel 4

Indikator Kegiatan pada Program Peningkatan Pelayanan Masyarakat

\begin{tabular}{|c|l|l|}
\hline No & \multicolumn{1}{|c|}{ Kegiatan } & \multicolumn{1}{c|}{ Indikator } \\
\hline 1 & $\begin{array}{l}\text { Fasilitasi kegiatan survey kegiatan } \\
\text { masyarakat pada masing-masing } \\
\text { perangkat daerah }\end{array}$ & Jumlah OPD yang melakukan SKM \\
\hline 2 & Evaluasi dan review SOP & $\begin{array}{l}\text { Jumlah perangkat daerah yang dievauasi dan di } \\
\text { review SOP }\end{array}$ \\
\hline 3 & $\begin{array}{l}\text { Pelaksanaan penilaian unit pelayanan } \\
\text { publik }\end{array}$ & $\begin{array}{l}\text { Jumlah UPP yang mendapatkan pendampingan } \\
\text { dengan baik }\end{array}$ \\
\hline 4 & $\begin{array}{l}\text { Pembinaan/ sosialisasi di bidang } \\
\text { ketatalaksanaan }\end{array}$ & $\begin{array}{l}\text { Jumlah OPD yang memahami ketentuan di } \\
\text { bidang ketatalaksanaan }\end{array}$ \\
\hline 5 & $\begin{array}{l}\text { Implementasi dan evaluasi } \\
\text { pelaksanaan reformasi birokrasi }\end{array}$ & $\begin{array}{l}\text { Jumlah laporan pelaksanaan reorasi birokrasi } \\
\text { kabupaten nganjuk yang tersusun dengan baik }\end{array}$ \\
\hline 6 & Inovasi pelayanan publik & Jumlah inovasi yang diinisiasi \\
\hline
\end{tabular}

Sumber : (Sekertariat Daerah Kabupaten Nganjuk, 2019)

\section{b. Capaian Kinerja Pelayanan Publik Di Kabupaten Nganjuk}

Pada makalah ini capaian kinerja pelayanan publik di Kabupaten Nganjuk dinilai berdasarkan indikator kinerja yang berorientasi pada hasil. Berikut ini merupakan pencapaian kinerja kegiatan pada program peningkatan pelayanan masyarakat tahun 2020:

Tabel 5

Capaian Kinerja Pelayanan Publik di Kabupaten Nganjuk

\begin{tabular}{|c|l|l|c|c|}
\hline \multirow{2}{*}{ No } & \multicolumn{1}{|c|}{ Kegiatan } & \multicolumn{1}{c|}{ Indikator } & \multicolumn{2}{c|}{ Capaian Kinerja } \\
\cline { 2 - 5 } 1 & $\begin{array}{l}\text { Fasilitasi kegiatan survey } \\
\text { kegiatan masyarakat } \\
\text { pada masing-masing } \\
\text { perangkat daerah }\end{array}$ & $\begin{array}{l}\text { Jumlah OPD yang melakukan } \\
\text { SKM }\end{array}$ & 48 OPD & 50 OPD \\
\hline 2 & Evaluasi dan review SOP & $\begin{array}{l}\text { Jumlah perangkat daerah } \\
\text { yang dievauasi dan di review } \\
\text { SOP }\end{array}$ & 48 OPD & 50 OPD \\
\hline 3 & $\begin{array}{l}\text { Pelaksanaan penilaian } \\
\text { unit pelayanan publik }\end{array}$ & $\begin{array}{l}\text { Jumlah UPP yang } \\
\text { mendapatkan pendampingan } \\
\text { dengan baik }\end{array}$ & 50 OPD & 50 OPD \\
\hline
\end{tabular}




\begin{tabular}{|c|l|l|l|l|}
\hline 4 & $\begin{array}{l}\text { Pembinaan/ sosialisasi di } \\
\text { bidang ketatalaksanaan }\end{array}$ & $\begin{array}{l}\text { Jumlah OPD yang memahami } \\
\text { ketentuan di bidang } \\
\text { ketatalaksanaan }\end{array}$ & 48 OPD & 50 OPD \\
\hline 5 & $\begin{array}{l}\text { Implementasi dan } \\
\text { evaluasi pelaksanaan } \\
\text { reformasi birokrasi }\end{array}$ & $\begin{array}{l}\text { Jumlah laporan pelaksanaan } \\
\text { reformasi birokrasi kabupaten } \\
\text { nganjuk yang tersusun dengan } \\
\text { baik }\end{array}$ & $20 \mathrm{buku}$ & $20 \mathrm{buku}$ \\
\hline 6 & Inovasi pelayanan publik & Jumlah inovasi yang diinisiasi & 50 OPD & 50 OPD \\
\hline
\end{tabular}

Sumber: (Sekertariat Daerah Kabupaten Nganjuk, 2019)

Berdasarkan data di atas, menunjukkan bahwa capaian kinerja pada program peningkatan pelayanan masyarakat sesuai dengan target yang direncanakan. Berikut ini merupakan analisis capaian kinerja yang berorientasi pada hasil, sesuai kerangka berfikir yang telah ditentukakan.

\section{a. Efektivitas}

Efektif berarti tercapainya suatu tujuan yang telah ditetapkan baik itu dalam bentuk target, sasaran jangka panjang maupun misi organisasi publik. Selain itu pencapaian tujuan program tersebut juga harus mengacu pada visi organisasi. Berikut ini merupakan hubungan antara optimalisasi pelayanan publik dan target, sasaran maupun visi dan misi Pemerintah Daerah Kabupaten Nganjuk.

Tabel 6

Efektivitas Penyelenggaraan Peningkatan Pelayanan Publik

\section{Visi :}

Terwujudnya Kabupaten Nganjuk yang manju dan Bermartabat (Nganjuk Nyawiji Bangun Deso Noto Kutho)

\section{Misi :}

Memperkut kinerja birokrasi yang bersih, professional, akuntabel yang berorientasi pada pelayanan publik yang berkualitas dan pro rakyat (Maju dan Bermartabat)

\begin{tabular}{|l|l|l|l|}
\hline Tujuan & Sasaran & Strategi & Arah Kebijakan \\
\hline Peningkatan tata & Meningkatnya & Melaksanakan & Fasilitasi dan \\
kelola dan & ketatalaksanaan & Survey Kepuasan & asistensi \\
reformasi & pemerintah yang & Masyarakat di & penyusunan \\
birokrasi & efektif dan efisien & Setiap OPD & Survey Kepuasan \\
\hline
\end{tabular}




\begin{tabular}{|l|l|l|l|}
\hline & $\begin{array}{l}\text { menuju } \\
\text { optimalisasi } \\
\text { pelayanan publik }\end{array}$ & $\begin{array}{l}\text { Masyarakat } \\
(\mathrm{SKM})\end{array}$ \\
\hline
\end{tabular}

Sumber: (Pemerintah Kabupaten Nganjuk, 2018)

Berdasarkan tabel di atas menunjukkan bahwa visi, misi, tujuan dan sasaran dalam peningkatan pelayanan publik saling bersinergi. Program peningkatan pelayanan publik sudah sesuai dengan visi, misi, tujuan dan sasaran di Kabupaten Nganjuk. Dengan demikian, program capaian kinerja pada peningkatan pelayanan masyarakat dapat dikatakan efektif.

\section{b. Kepuasan}

Kepuasan dinilai berdasarkan seberapa jauh organisasi publik dapat memenuhi kebutuhan pegawai dan masyarakat. Dalam rangka menilai kepuasan pelayanan publik di Kabupaten Nganjuk, indikator yang digunakan adalah survey kepuasan masyarakat. Berikut survey kepuasan masyarakat di Inspektorat Kabupaten Nganjuk terhadap penyelenggaraan pelayanan publik pemerintah kabupaten Nganjuk tahun 2019.

\section{Tabel 7}

Nilai Rata-Rata Unsur Pelayanan

\begin{tabular}{|c|c|c|}
\hline No. & Unsur Pelayanan & Nilai Rata-rata \\
\hline U1 & Persyaratan & $\left.3,46^{\star \star}\right)$ \\
\hline U2 & Sistem, mekanisme, dan prosedur & 3,63 \\
\hline U3 & Waktu Penyelesaian & 3,75 \\
\hline U4 & Biaya/Tarif & 3,63 \\
\hline U5 & Produk Spesifikasi Jenis Pelayanan & 3,48 \\
\hline U6 & Kompetensi Pelaksana & 3,58 \\
\hline U7 & Perilaku Pelaksana & 3,66 \\
\hline U8 & Sarana dan prasarana & 3,63 \\
\hline U9 & $\begin{array}{l}\text { Penanganan Pengaduan, Saran dan } \\
\text { Masukan }\end{array}$ & $\left.3,95^{*}\right)$ \\
\hline \multicolumn{3}{|c|}{ Keterangan: } \\
\hline \multicolumn{3}{|c|}{ - U1 s/d U9 : Unsur-unsur pelayanan } \\
\hline \multicolumn{3}{|c|}{ - NRR $\quad$ : Nilairata-rata } \\
\hline \multicolumn{3}{|c|}{ : NilaiTertinggi } \\
\hline \multicolumn{3}{|c|}{ : NilaiTerendah } \\
\hline
\end{tabular}

Sumber: (Inspektorat Daerah, 2019) 
Berdasarkan hasil analisis terhadap penilaian survey kepuasan masyarakat tersebut menunjukkan bahwa nilai IKM (Indeks Kepuasan Masyarakat) pada Inspektorat Daerah Kabupaten Nganjuk adalah 90,88.

Tabel 8

Standar Penilaian Mutu Pelayanan dan Kinerja Unit Pelayanan

\begin{tabular}{c|c|c|c|c|}
$\begin{array}{c}\text { Nilai } \\
\text { Persepsi }\end{array}$ & interval IKM & $\begin{array}{c}\text { Nilai Interval } \\
\text { Konversi IKM }\end{array}$ & $\begin{array}{c}\text { Mutu } \\
\text { Pelayanan }\end{array}$ & $\begin{array}{l}\text { Sinerja Unit } \\
\text { Pelayanan }\end{array}$ \\
\hline 1 & $1,00-2,5996$ & $25,00-64,99$ & D & Tidak baik \\
\hline 2 & $2,60-3,064$ & $65,00-76,60$ & C & Kurang baik \\
\hline 3 & $3,064-3,532$ & $76,61-88,30$ & B & Baik \\
\hline 4 & $3,532-4,00$ & $88,31-100,00$ & A & Sangat baik \\
\hline
\end{tabular}

Sumber : (Inspektorat Daerah, 2019)

Berdasarkan tabel di atas, dengan nilai IKM sebesar 90,88 pada Inspektorat Daerah Kabupaten Nganjuk menunjukkan bahwa kinerja unit pelayanan dan mutu pelayanan pada Inspektrorat "sangat baik"

\section{KESIMPULAN DAN REKOMENDASI}

Optimalisasi penyelenggaraan pelayanan publik dalam mewujudkan tata kelola pemerintah yang efektif dan efisien berdasarkan kinerja OPD di Kabupaten Nganjuk dianalisis menggunakan konsep kinerja dengan indikator capaian kinerja yang berorientasi pada hasil. Aspek yang digunakan untuk analisis adalah efektivitas dan kepuasan. Berdasarkan hasil analisis menunjukkan bahwa kinerja pemerintah daerah Kabupaten Nganjuk dalam peningkatan pelayanan publik sudah dilakukan secara optimal. Dimana target dalam rencana kerja semua terpenuhi. Selain itu program peningkatan pelayanan publik sudah sesuai dengan visi, misi, tujuan dan sasaran di Kabupaten Nganjuk. Dengan demikian, program capaian kinerja pada peningkatan pelayanan masyarakat dapat dikatakan efektif. Terkait dengan kepuasan masyarakat, pemerintah kabupaten Nganjuk juga mengintruksikan untuk seluruh OPD nya untuk membuat survey 
kepuasan masyarakat. Dari data tersebut sudah 50 OPD yang melaksanakan instruksi tersebut dari target 50 OPD. Akan tetapi, publikasi terkait hasil Survey Kepuasan Masyarakat (SKM) belum semua OPD mempublikasikan hasilnya. Hanya beberapa OPD saya yang mempublikasikan hasil SKM secara online.

Berdasarkan kesimpulan di atas, maka rekomendasi untuk peningkatan kinerja pelayanan publik di kabupaten Nganjuk adalah untuk masing-masing OPD hendaknya mempublikasikan hasil SKM pada web masing-masing OPD. Selain itu juga harus rutin dan konsisten mempublikasikan hasil SKM nya tersebut. Dengan demikianmasyarakat bisa melihat trend kinerja OPD berdasarkan survey kepuasan masyarakat terhadap kinerja OPD.

\section{REFERENSI}

Hardiyansyah. (2018). Kualitas Pelayanan Publik: Konsep, Dimensi, Indikator dan Implementasinya. Gava Media.

Inspektorat Daerah. (2019). Laporan Hasil Survei Kepuasan Masyarakat (SKM) Terhadap Penyelenggaraan Pelayanan Publik Pemerintah Kabupaten Nganjuk Tahun 2019. 284.

Keban, Y. T. (2004). Enam dimensi strategis administrasi publik. Konsep, Teori Dan Isu, Jakarta: Gava Media.

Kurniawan, R. C. (2016). Tantangan Kualitas Pelayanan Publik Pada Pemerintah Daerah. Jurnal Ilmiah Administrasi Publik Dan Pembangunan, 7(1), 15.

Mahmudi. (2005). Manajemen Kinerja Sektor Publik. Akademi Manajemen Perusahaan YKPN, Yogyakarta.

Mahsun, M. (2006). Pengukuran kinerja sektor publik. Yogyakarta: BPFE.

Menpan. (2004). Pedoman Umum Penyusunan Indeks Kepuasan Masyarakat Unit Pelayanan Instansi Pemerintah. Jakarta.

Oliver, R. L., \& Rust, R. T. (1994). Service quality: Insights and managerial implication from the frontier. Journal of Service Quality, 15(4), 32-43.

Osborne, D. (1993). Reinventing government. Public Productivity \& Management Review, 349-356.

Pemerintah Kabupaten Nganjuk. (2018). RENCANA STRATEGIS SEKERTARIAT DAERAH KABUPATEN NGANJUK TAHUN 2018-2023. 1-26.

Puspitasari, F. F. (2019). Implementasi Pelayanan Prima Sebagai Upaya Meningkatkan 
Marketing Sekolah. J-MPI (Jurnal Manajemen Pendidikan Islam), 4(1).

Ratminto, \& Winarsih, A. S. (2007). Manajemen Pelayanan. Yogyakarta.

Sedarmayanti. (2004). Good governance (kepemerintahan yang baik): bagian kedua: membangun sistem manajemen kinerja guna meningkatkan produktivitas menuju good governance (kepemerintahan yang baik). Mandar Maju.

Sekertariat Daerah Kabupaten Nganjuk. (2019). Rencana Kerja Sekertariat Daerah Tahun 2020. 7(26).

Sudarmanto, K. (2009). Pengembangan Kompetensi SDM. Yogyakarta: Pustaka Pelajar.

Sulistiyani, A. T., \& Rosidah. (2003). Manajemen sumber daya manusia: konsep, teori dan pengembangan dalam konteks organisasi publik. Graha Ilmu.

Sutopo, A. S. (2003). Pelayanan Prima, Modul Pendidikan dan Pelatihan Prajabatan Golongan I dan II. Lembaga Administrasi Negara.

Wood, J. A. (2008). The effect of buyers' perceptions of environmental uncertainty on satisfaction and loyalty. Journal of Marketing Theory and Practice, 16(4), 309-320. 